\title{
Sublingual Spray, Solution Dosage Form
}

National Cancer Institute

\section{Source}

National Cancer Institute. Sublingual Spray, Solution Dosage Form. NCI Thesaurus. Code C149958.

Liquid, usually multidose preparation consisting of a solution intended for sublingual use. Sublingual sprays are usually presented in pressurized containers with a metering valve. 